\title{
Cyclization of Semicarbazones to 1,2,3-Selenadiazoles By Selenium Dioxide
}

\author{
Omar Th. Ali Al-Obaidy \\ Department of Chemistry / College of Education \\ University of Mosul
}

Received

$28 / 11 / 2010$
Accepted

09 / 02 / 2011

\begin{abstract}
الخلاصة

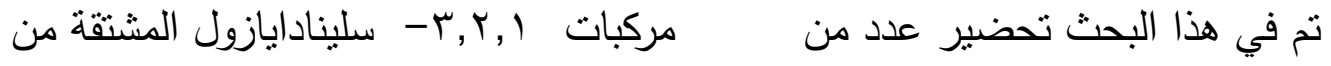

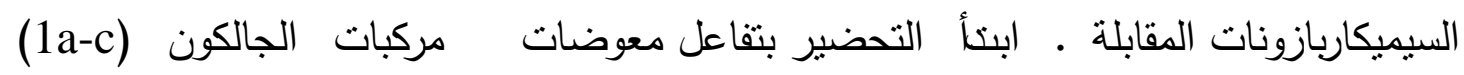

وباراميثوكسي بنزايل سيانيد ليعطي المركبات (2a-c) التي حولت من خلال التفاعل مع

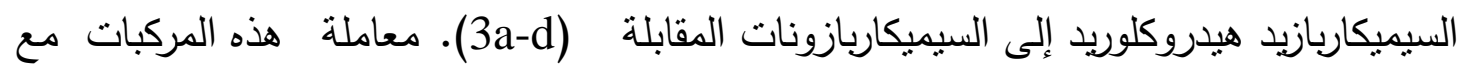

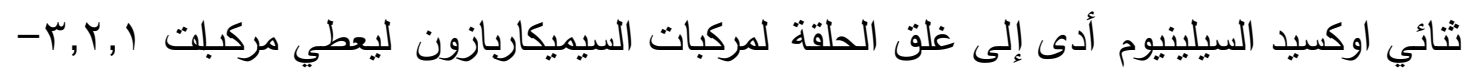
سلينادايازول. شخصت المركبات المضرة بالطرق الطيفية والفيزياوية .
\end{abstract}

\begin{abstract}
In the present work some of 1,2,3-selenadiazole compounds derived from corresponding semicabazones have been prepared. The reaction of substituted chalcone compounds (1a-c) and 4-methoxy benzyl cyanide give compounds $(2 \mathrm{a}-\mathrm{c})$ which were converted through the reaction with semicarbazide hydrochloride into the corresponding semicarbazones (3a-d). The treatment of these compounds with selenium dioxide leads to ring closure of semicarbazones to give the 1,2,3-selenadiazole compounds. The structures of the synthesized compounds were established by physical and spectral methods.
\end{abstract}

\section{Introduction}

In the last years heterocyclic compounds containing selenium atom are of considerable chemical and biochemical interest due to their synthetic and biological applications, they are similar in chemical and physical properties with the corresponding organo-sulfur compounds but not identical in bond stability ${ }^{(1-3)}$. Selenium compounds are less stable on exposure to light or heat and are more easily oxidized than their sulfur analogous due to the larger size of the selenium atom and an increased in polarizability, therefore they are in general, less stable than the corresponding sulfur analogues ${ }^{(4)}$. Selenols and selenide anions are more 
potent nucleophiles with a greater facility for carbon bonding than their corresponding sulfur-anions, organo-selenium compounds are extremely unpleasant and had pervasive odors, nowadays remarkable level of interest among chemists and biochemists in organo-selenium compounds, This has been increased particularly with the growing recognition of their key roles in biological processes, not least their potential as possible anti carcinogens $^{(5)}$. A considerable number of selenium analogous of organosulfur compounds are known and many of them have been isolated from biological materials and their properties were investigated ${ }^{(6)}$. Although some aspects of the metabolism of organo-sulfur compounds resemble those of their sulfur analogous, their metabolic pathways diverge considerably. Many have also been synthesized and their possible uses, industrially and medicinally, have been investigated ${ }^{(7)}$. The particular interest from the nutrition point of view are the selenoaminocarboxylic acids, selenium-containing peptides, and selenium derivatives of nucleic acids that occur naturally in body cells and tissues. ${ }^{(8)}$. Heterocyclic systems containing 1,2,3-selenadiazole ring was recently investigated and prepared by several workers ${ }^{(9)}$, as they are not only versatile intermediates $^{(10)}$, but also have attracted much attention for their antifungal $^{(11)}$, antibacterial ${ }^{(12)}$, antimicrobial ${ }^{(13)}$ and insecticidal activities $^{(14)}$.

\section{EXPERIMENTAL}

All chemicals were purchased from Fluka and BDH Chemical Ltd. The melting points were measured on an Electrothermal 9300 Engineering LTD and were uncorrected. IR spectra were recorded on Infrared Spectrophotometer Model Tensor 27, Bruker Co., Germany, using $\mathrm{KBr}$ discs. The UV spectra were recorded on UV-Visible Shimadzu 1601 Spectrophotometer.

General procedure for the preparation of 3-(4-methoxyphenyl)-1(aryl)-2-propene-1-one $\left(1_{\mathrm{a}-\mathrm{c}}\right)^{(15,16)}$.

In a round bottom flask provided with mechanical stirrer, a solution of $(5 \mathrm{ml})(10 \% \mathrm{NaOH})$ and $(80 \mathrm{ml})$ of $\mathrm{EtOH}$ was placed. A mixture of $(0.25$ mole $)$ of substituted acetophenone and $(0.25$ mole $)$ of 4-methoxybenzaldehyde were added with vigorous stirring and the stirring continued for $45 \mathrm{~min}$. The produced precipitate was filtered off ,washed with cooled water and recrystallized from ethanol.The physical and spectral data are given in Table (1).

General procedure for the preparation of 2,3-bis (4-methoxyphenyl) -4-substituted benzoyl butyronitrile $\left(2_{\text {a-c }}\right)^{(17)}$.

4-Methoxy benzyl cyanide (0.08 mole) was added to different chalcones $\left(1_{\mathrm{a}-\mathrm{c}}\right)$ (0.08 mole) as ether solution in presence of sodium ethoxide $(0.016$ mole) in ethanol. The reaction mixture was kept at room temperature for about 20 hours. Acidification of the mixture by adding a few drops of acetic acid gave a precipitate which was recrystallised from ethanol to get compounds $\left(2_{\mathrm{a}-\mathrm{c}}\right)$. 
General procedure for the preparation of 1-[(4-cyano-3,4-bis(4methoxyphenyl)-1-arylbutylidene)] $\operatorname{semicarbazone}\left(3_{\mathrm{a}-\mathrm{c}}\right)^{(18)}$.

To a warm solution of ( 0.01 mole) of the appropriate ketone $\left(2_{\mathrm{a}-\mathrm{c}}\right)$ in $(30 \mathrm{ml})$ of ethanol, a solution of equimolar amount $(0.07$ mole $)$ of semicarbazide hydrochloride and sodium acetate in $(20 \mathrm{ml})$ of water was added and the mixture was refluxed for $4 \mathrm{hrs}$. The solution was cooled and poured on to crushed ice and extracted with chloroform. The solvent was evaporated and the product was recrystallized from ethanol. The physical and spectral data of new 1-[(4-cyano-3,4-bis(4-methoxyphenyl) -1-arylbutylidene)] semicarbazone $\left(3_{\mathrm{a}-\mathrm{c}}\right)$ are given in Table (1).

\section{Synthesis of substituted 1,2,3-selenadiazole compounds $\left(4_{\mathrm{a}-\mathrm{c}}\right)^{(19)}$.}

A solution of ( 0.007 mole) of the appropriate semicarbazones and (0.07 mole) of powdered selenium dioxide in dry THF was gently heated on a water bath with stirring for two hours. The selenium deposited on cooling was removed by filtration, and the filtrate was poured into crushed ice, the precipitate was filtered off, washed with cold water and recrystallized from ethyl alcohol to give the selenadiazole compounds $\left(4_{\mathrm{a}-\mathrm{c}}\right)$. The physical and spectral data of the products 2,3-bis(4methoxyphenyl)-3-(4-aryl-1,2,3-selenadiazole-5-yl) acrylonitrile $\left(4_{\mathrm{a}-\mathrm{c}}\right)$ are given in Table (1).

Table (1): physical and spectral data for compounds $\left(1_{\mathrm{a}-\mathrm{c}}-\mathbf{4}_{\mathrm{a}-\mathrm{c}}\right)$

\begin{tabular}{|c|c|c|c|c|c|c|c|c|c|c|c|c|c|c|c|}
\hline \multirow{3}{*}{\multicolumn{2}{|c|}{$\begin{array}{c}\text { Comp. } \\
\text { No. }\end{array}$}} & \multirow{3}{*}{$X$} & \multirow{3}{*}{$\begin{array}{c}\text { Yield } \\
\%\end{array}$} & \multirow{3}{*}{${ }^{\circ} \mathrm{C} . \mathrm{p}}$. & \multicolumn{11}{|c|}{$\mathrm{IR} v\left(\mathrm{~cm}^{-1}\right) \mathrm{KBr}$} \\
\hline & & & & & \multicolumn{3}{|c|}{$\mathrm{C}=\mathrm{O}$} & \multirow{2}{*}{$\mathrm{C}=\mathrm{C}$} & \multirow{2}{*}{$\mathrm{C}=\mathrm{N}$} & \multirow{2}{*}{$\begin{array}{c}\mathrm{NO}_{2} \\
\text { asym,sym }\end{array}$} & \multirow{2}{*}{$\mathrm{N}-\mathrm{H}$} & \multirow{2}{*}{$\begin{array}{c}\text { C-Se- } \\
\text { N }\end{array}$} & \multirow{2}{*}{$\mathrm{C} \underset{\mathrm{Ar}}{\cdots}$} & \multirow{2}{*}{$\begin{array}{c}\mathrm{C}-\mathrm{H} \\
\text { aliphatic }\end{array}$} & \multirow{2}{*}{$\begin{array}{c}\text { U.V. } \\
\lambda_{\max } \mathrm{nm} \\
\mathrm{EtOH}\end{array}$} \\
\hline & & & & & Coni & ketone & amide & & & & & & & & \\
\hline \multirow{3}{*}{1} & $\mathrm{a}$ & $\mathrm{H}$ & 72 & 181 & 1669 & - & - & 1624 & - & - & - & - & 1594 & 2947 & $\begin{array}{l}248, \\
302\end{array}$ \\
\hline & $\mathrm{b}$ & $4-\mathrm{NO}_{2}$ & 63 & 175 & 1668 & - & - & 1627 & - & 1545,1344 & - & - & 1541 & 2952 & $\begin{array}{l}230, \\
324\end{array}$ \\
\hline & $\mathrm{c}$ & $3-\mathrm{NO}_{2}$ & 70 & 167 & 1665 & - & - & 1622 & - & 1583,1342 & - & - & 1541 & 2933 & $\begin{array}{l}235, \\
321\end{array}$ \\
\hline \multirow{3}{*}{2} & $\mathrm{a}$ & $\mathrm{H}$ & 47 & 160 & - & 1689 & - & - & - & - & - & - & 1555 & 2945 & 312 \\
\hline & $\mathrm{b}$ & $4-\mathrm{NO}_{2}$ & 51 & 168 & - & 1687 & - & - & - & 1541,1341 & - & - & 1595 & 2929 & 294 \\
\hline & $\mathrm{c}$ & $3-\mathrm{NO}_{2}$ & 59 & 163 & - & 1690 & - & - & - & 1534,1346 & - & - & 1607 & 2925 & 297 \\
\hline \multirow{3}{*}{3} & $\mathrm{a}$ & $\mathrm{H}$ & 46 & 144 & - & - & 1698 & - & 1635 & & 3445 & - & 1605 & 2928 & 334 \\
\hline & $\mathrm{b}$ & $4-\mathrm{NO}_{2}$ & 68 & 171 & - & - & 1695 & - & 1647 & 1522,1343 & 3410 & 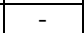 & 1608 & 2957 & 341 \\
\hline & $\mathrm{c}$ & $3-\mathrm{NO}_{2}$ & 62 & 168 & - & - & 1699 & - & 1639 & 1520,1345 & 3456 & - & 1595 & 2932 & 317 \\
\hline \multirow{3}{*}{4} & $\mathrm{a}$ & $\mathrm{H}$ & 50 & 111 & - & - & - & 1638 & - & - & - & 832 & 1603 & 2923 & - \\
\hline & $\mathrm{b}$ & $4-\mathrm{NO}_{2}$ & 38 & 147 & - & - & - & 1631 & - & 1537,1344 & - & 820 & 1593 & 2918 & - \\
\hline & $\mathrm{c}$ & $3-\mathrm{NO}_{2}$ & 53 & 152 & - & - & - & 1635 & - & 1566,1341 & - & 827 & 1600 & 2922 & - \\
\hline
\end{tabular}

\section{RESULTS AND DISCUSSION}

In the present work the synthesis of 1,2,3-selenadiazole derivatives (4a-c) were studied (scheme 1). The synthetic procedure started from the 4-methoxy benzaldehyde and substituted acetophenone in ethanol in presence of $\mathrm{NaOH}$ to produce chalcone compounds (1a-c), their IR spectra showed $v^{-1}$ at $(1665-1669)$ due to $(C=O)$ group and (1622-1627) due to $(\mathrm{C}=\mathrm{C})$ conjugated system, UV spectra showed maximum absorption at $324 \mathrm{~nm}$ (Table1). In the synthesis of heterocyclic compounds containing selenium atom, the cyano group has the most fruitful utility ${ }^{(20,21)}$, since compounds possessing nitrile functionality act as channel blockers and are the first drugs of choice for the management of angina ${ }^{(22)}$.Compounds (1a-c) were treated with 4-methoxy benzyl 
cyanide to give corresponding ketones (2a-c) which gave IR absorption bands $\mathrm{vcm}^{-1}$ at $(1687-1690)$ due to $(\mathrm{C}=\mathrm{O})$ group, UV spectra showed maximum absorption at $312 \mathrm{~nm}$. The reaction of ketones (2a-c) with semicarbazide hydrochloride gave the corresponding semicarbazones (3a-c) their IR spectra showed $v \mathrm{~cm}^{-1}$ at $(1695-1699)$ due to amide $(\mathrm{C}=\mathrm{O})$ group, (3410-3456) due to $(\mathrm{NH})$ and $(1635-1647)$ related to $(\mathrm{C}=\mathrm{N})$ group, UV spectra showed maximum absorption at $341 \mathrm{~nm}$. The target heterocyclic compounds (4a-c) produced by the treatment of the corresponding semicarbazones ( $3 \mathrm{a}-\mathrm{c})$ with selenium dioxide in dry T.H.F showed IR absorption bands $v \mathrm{~cm}^{-1}$ at $(820-832)$ due to $(\mathrm{C}-\mathrm{Se}-\mathrm{N})^{(23)}$.

$\mathbf{3}_{\mathrm{a}-\mathrm{c}}$

$$
\mathbf{4}_{\mathrm{a}-\mathrm{c}}
$$

$\mathrm{X}=\mathrm{H}, 4-\mathrm{NO}_{2}, 3-\mathrm{NO}_{2}$

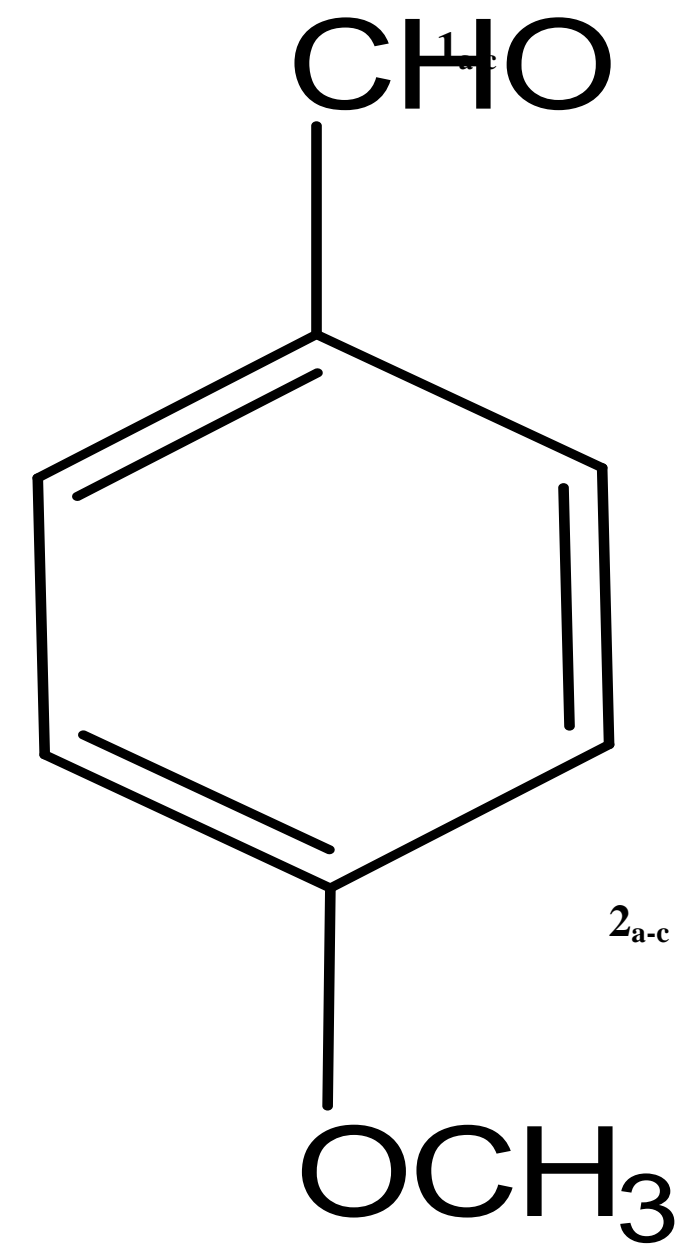

Scheme (1) 


\section{References}

1) M. A. Abramove, W. Dehaen, B.D‘ Hooge, M. L. Ppetrove, S. Smeets, S. Toppet and M. Votes., Tetrahedron, 56, 3933, 2000.

2) E. B. Moawad, M. Y Yousif, and M.A. Metwally., Pharmazie,44, $820,1989$.

3) K. Kuroda, T. Uchikurohane, S. Tajima and K. Tsubata., US Pat., US 6166, 054; Chem. Abstr.,134, 38255, 2001.

4) B. D' Hooge, S. Smeet, S. Toppet, S. Dehaeam., J. Chem. Soc., 1753, 1997.

5) C. Rielly, "Selenium in Food and Health", $2^{\text {nd }}$ ed., Springer Science \& Business Media, LLC, 233, NY10013, 5-7, 2006.

6) H. S. El-Kashef, B. E-Bayoumy, and T. I. Aly., Egypt. J. Pharm. Sci., 27, 113, 1986.

7) T. Sasaki., Japan Pat., 70, 27, 573; Chem. Abstr., 74, 3629, 1971.

8) V. A. Bakulev and W. Dehaen, "The Chemistry of 1,2,3Thiadiazoles", John Wiley \& Sons, Inc., NY.,193-228, 2004.

9) D. B. Reddy, A. S. Reddy \& V. Padmavathi., Synth. Commun. 31, 3429.2001.

10) (a) W. Ando and N. Tokitoh., Heteroatom chem., 1.1991, (b) M. Al- smadi, S. Ratrout, J. Heterocycl. Chem., 41, 887.2004.

11) M. M. Kandeel, S. El-Meligie, R. H. Omar, S. A. Roshdy and K. M. Youssef., Chem. J. Pharm. Sci. 3,197.1994.

12) B. M. Patil, B. V. Badami \& G. S. Puranik., Indian. J. Heterocycl Chem., 3, 193, 1994.

13) M. Koketsu and H. Ishihara, Curr. Org. Chem., 7, 175, 2003.

14) V. Padmavathi, R. P. Sumathi \& A. Padmaja., J.Ecobiol., 14, 9, 2002.

15) D. N. Dhar., "The Chemistry of Chalcone and Related Compounds"., John Wiley and Sons., Inc., 214-215,1981.

16) A. I. Vogel., "Textbook of Practical Organic Chemistry", $4^{\text {th }}$ ed., Longman, London,796,345,1978.

17) S. Saravanan, Sh. Athimoolam. and Sh. Muthusubramanian., "Synthesis and characterization of 3-aryl-3-[4-aryl-1,2,3selenadiazol-5-yl]-2-phenyl-2-propenenitrile", Indian. J. Chem., 22-33, 2007.

18) M. Al-Smadi and S. Ratrout., "New Multi-1,2,3-Selenadiazole Aromatic Derivatives"., J. Org. Molecules, 10, 1126-1134, 2005.

19) T. I. El-Emary, N. Al-Muaikel, and O. S. Moustafa, "Synthesis And Antimicrobial Activity of Some New Heterocycles Based On 3-Methyl-1-Phenyl-5-Benzene Sulfonamido Pyrazole"., Taylor \& Francis 1042-6507/02, 177:195-210, 2002.

20) V. J. Grenda, R. E. Jones, G. Gal \& M. Sletzinger., J. Org. Chem. 30, 259. 1965.

21) S. Sarananan and A. Amuthavalli, Indian. J. Chem.Vol,48B,11441147,2009 .

22) L. J. Theodore and W. L. Nelson., J. Org. Chem. 52, 1309. 1987.

23) Saravanan, S.; Nithya, A.; Muthusubramanian. S. J. Heterocycl. Chem., 43, 149, 2006. 